\title{
BARTHA-Kovács Katalin \\ „Egyetlen vércsepp sem hull a földre tőre hegyéről”
}

\author{
Médeia-ábrázolások a 17-19. századi francia festészetben \\ és művészetkritikai írásokban
}

A tanulmány címében szereplő idézet Diderot első, 1759-es Szalonjából származik. A művészetkritikus meglehetősen lesújtó véleménnyel van a Franciaországban letelepedett, holland származású festőcsalád leghíresebb sarja, Carle Vanloo Iaszón és Médeia címü festményéről. Ezt írja róla: „Egyetlen vércsepp sem hull a földre tőre hegyéről vagy csorog le a karján; nyoma sincs zilált kuszaságnak; nyoma sincs rettenetnek." Diderot-nak valószínúleg jobban tetszett volna Eugène Delacroix 1838-ban, a Louvreban kiállított Örjöngő Médeiája, amely a történet egy másik jellemző momentumát ragadja meg: nem azt a jelenetet ábrázolja, amelyben Médeia sárkányfogatán elrepül, hanem a gyermekgyilkosságot közvetlenül megelöző pillanatot. A korabeli művészetkritikusok is elismerő szavakkal méltatták Delacroix képét, amely - Théophile Gautier szavaival - „feldúlt Médeiát” ábrázol, aki „kezében tőrrel, zilált öltözékben mintha szét akarná feszíteni a kép keretét".

A két kép elkészülte között eltelt mintegy nyolcvan év alatt a francia müvészeti élet számos tekintetben megváltozott. Míg Vanloo festményei a rokokó és a neoklasszicista stílusirányzatokhoz sorolhatók, addig a 19. század első fele a romantikus művészet virágkora, amelynek Delacroix az egyik vezéralakja. Ugyancsak lényeges változás, hogy a felvilágosodás korában kialakuló művészetkritika a következő században teljes mértékben polgárjogot nyert. Bár nem Diderot a szó szoros értelmében vett első művészetkritikus - és kéziratos formában terjesztett Szalonjait csupán néhány koronás fö, a Correspondance littéraire (Irodalmi Levelezés) előfizetöi olvasták, maguk a megbírált festők azonban nem ismerték -, mégis vele kezdődik Franciaországban az irodalmárok művészetkritikája. E műfaj legjelesebb képviselői a következő században is mind neves írók és költők, hogy csak néhányat említsünk közülük: Stendhal, Baudelaire, a Goncourt-fivérek vagy a müvészet függetlenségét és öncélúságát hirdető l’art pour l’art mozgalom szószólója, Théophile Gautier.

\footnotetext{
${ }^{1}$ Denis Diderot, Salon de 1759 = D. D., Essais sur la peinture: Salons de 1759, 1761, 1763, éd. Jacques Chouillet, Gita MaY, Paris, Hermann, 1984, 92. (Ha az idézeteknek nincs nyomtatásban megjelent magyar nyelvű fordítása, akkor azokat a saját fordításomban közlöm. - B.-K. K.) Charles André van Loo (1705-1765) a francia művészeti Akadémia igazgatója. Templomok és paloták freskói mellett életképeket, valamint turquerie-stílusban készült, elegáns arcképeket festett. Mivel a 18. századi francia nyelvű művészetkritikai szövegek szerzői rendszerint Carle Vanloo néven említik a festőt, tanulmányomban én is ezt a névváltozatot használom.

2 Théophile Gautier, Exposition du Louvre (22 mars 1838) = Charles Baudelaire, Théophile GaUtier, Correspondances esthétiques sur Delacroix, préface Stéphane GuÉGAN, Paris, Éditions Olbia, 1998, 34.
} 
A tanulmányban három, 18. és 19. századi francia művész (Pierre, Vanloo és Delacroix) által készített Médeia-festményt - illetve Vanloo esetében három képváltozatot mutatok be, ismertetve a róluk írt művészetkritikai szövegeket, illetve szólni fogok egy 17. századi, Médeiát ábrázoló Poussin-rajzról is. A kritikai írások elemzése kettős célt szolgál: egyrészt rávilágít arra, hogyan változott meg a Médeia-téma felfogása és feldolgozása a francia festészetben, másrészt bemutatja a téma ábrázolásának müvészetkritikai fogadtatásában lezajlott változást. Ezzel összefüggésben több kérdést is vizsgálok, például, hogy milyen szempontokat helyeznek előtérbe a Szalon-kritikák szerzői. Ezek összhangban vannak-e az elemzett képpel, vagy a kritikusok a festmények elemzésének ürügyén inkább saját, művészetről vallott elveiket szemléltetik? Mit értékelnek pozitívan és mit bírálnak a képeken? Ebből milyen általánosabb következtetések vonhatók le? Arra is szeretnék választ kapni, hogy a müvészetben bekövetkezett stílusváltozások mennyiben befolyásolták a Médeia-ábrázolásokat. Reményeim szerint a francia nyelvű művészetkritikai szövegek új szempontokkal gazdagíthatják a Médeia-értelmezéseket.

\section{Egy 17. századi elökép: Poussin rajza}

A Médeia-motívum első jelentősebb ikonográfiai feldolgozása a francia művészetben egy - a klasszicista stílusirányzat emblematikus festöjének - Nicolas Poussin-nek tulajdonított, 1645-ben keletkezett rajz. E rajz szerepe a festő életmüvében nincs pontosan tisztázva: nem tudni, tanulmánynak szánta-e valamely később megfestendő képhez, vagy más céllal készült, Poussin-től ugyanis nem maradt fenn Médeiát ábrázoló festmény. Azért feltételezhető mégis, hogy ő a rajz készítője, mert egyik biográfusa, az itáliai Giovan Pietro Bellori életrajzában olvasható egy képleírás, amelynek az említett rajz megfelel. ${ }^{3}$ Bellori tragikusnak nevezi a képen látható őrjöngő Médeiát, aki

[...] lábánál fogva tartja gyermekét, és feldühödött anyatigrisként felemeli a tőrét, hogy torkon szúrja. A mellette ülő dajka, aki a másik, már meggyilkolt gyermeket az ölében tartva sír, kinyújtott kézzel Médeia felé fordul, elborzadva az iszonyatos rémtett láttán. Iasón, a szerencsétlen atya, széttárt

\footnotetext{
${ }^{3}$ Voltaképpen két, egymáshoz erősen hasonlító, Médeiát ábrázoló Poussin-rajz is ismeretes. Ezek közül Bellori leírása az alábbinak felel meg: Nicolas Poussin, Médée tuant ses enfants (Médeia megöli gyermekeit), 1645 körül, tollrajz, 25,7 × $20 \mathrm{~cm}$, Windsor Castle, Royal Library. http://utpictura18.univ-montp3.fr/ GenerateurNotice.php?numnotice=A0270 (Letöltés ideje: 2017. június 12.) - E rajzok eredetiségét illetően megoszlanak a vélemények, de Walter Friedländer és Anthony Blunt müvészettörténészek szerint Poussintöl származnak. Vö. Walter Friedländer, Anthony Blunt, The Drawings of Nicolas Poussin, London, University of London, 1939-1974, 5 kötet (a katalógusban szereplő 142. és 143. számú rajzok). Idézi Zoé SchweItZer, Médée, le spectateur de la violence. http://www.paris-sorbonne.fr/IMG/pdf/CRHT_Zoe_ Schweitzer_Medee_le_spectateur_de_la_violence.pdf (Letöltés ideje: 2017. június 12.)
} 
karral, egész testével kihajol egy erkélyről, és hiába szólítgatja őrült hitvesét. A szörnyü tett láttán Pallasz Athéné szobra csodálatos mozdulattal pajzsát emeli arca elé, hogy ne kelljen látnia ezt a rémséges gyilkosságot. Amint azt az ókori szerzőknél olvashatjuk, a szobrok ilyen mozdulatot tettek, valahányszor felfoghatatlan csodát láttak. ${ }^{4}$

Hangsúlyoznunk kell, hogy a Bellori-idézet nem műkritika, hanem képleírás, még akkor is, ha túlmutat az ekphraszisz hagyományán. Életrajzgyüjteményében Bellori tizenkét, Rómához köthető festő bemutatására vállalkozik: az itáliai művészek után említi meg Poussint, akit személyesen ismert. Úgy írja le a festő néhány jelentősebb alkotását, hogy dramatizálja és a retorika eszközeivel megeleveníti őket, mintha a festészet „néma költészet" volna, amelyet szóra kell bírni. Poussin Médeia-rajzát is életre kelti a leírás, a rajta látható hat emberalakot éppúgy, mint a festő invencióját: Pallas Athéné - pajzsát arca elé emelő - szobrát, amely a kép nézőjétől várt vagy várható reakciót jeleníti meg.

A rajzon - Iasón és a szobor között - azonban egy nőalak is feltünik, aki nem szerepel sem Euripidés, sem Seneca tragédiájának zárójelenetében. Valószínűleg ez a két szöveg szolgált a rajz alapjául, nem pedig Pierre Corneille első tragédiája, az 1635-ös Médeia. ${ }^{5}$ A Poussin rajzán szereplő nőalak - aki kezével rémült mozdulatot tesz - a tragédia egyik konkrét szereplőjével, így Kreón lányával (Iasón menyasszonyával) sem azonosítható, mivel az irodalmi hagyomány szerint ő már halott volt a gyermekgyilkosság pillanatában. Helytállóbbnak tünik az a feltételezés, mely szerint a nőalak a jelenet képbeli nézője, akivel a valódi néző azonosulhat. Ez az ikonográfiai megoldás amely Leon Battista Alberti festészetelméleti traktátusában is szerepel ${ }^{6}$ - a nézőnek a kép cselekményébe való bevonásával függ össze. A „közvetítő alak” a képhez tartozik, de egyszersmind a festményen kívüli világra is utal. Ezt a megoldást, vagyis egy „közvetítő alak" bevonását a festménybe, a 17. századi festők is előszeretettel alkalmazzák: a Médeia-rajz mellett Poussin egyik legismertebb festményén, az Árkádiai pásztorokon is megjelenik.7 Véleményem szerint azonban a képbeli Iasón mellett szereplő rejtélyes

\footnotetext{
${ }^{4}$ Giovan Pietro Bellori, Vie de Poussin (1672) = Bellori, Félibien, Passeri, Sandrart, Vies de Poussin, éd. critique Stefan Germer, Paris, Macula, 1994, 97-98. (A Bellori-idézet a fenti kiadásban szereplő, Nadine Blamoutier francia fordításának általam készített magyar változata, B.-K. K.)

${ }^{5}$ Médeia címü tragédiájában Corneille nem viszi színre a gyermekgyilkosságot. Míg az ő hősei emberfelettiek, és gyakran nem az ész törvényei, hanem szenvedélyeik vezérlik őket, addig Poussin képalakjai általában emberiek és racionális módon cselekednek. Lásd Anthony BLunT, Art et architecture en France 1500-1700, Paris, Macula, 1983, 241-242.

${ }^{6}$ „Helyesnek tartom továbbá, ha van valaki a történetben, aki figyelmeztet, és felhívja a figyelmünket arra, amit benne véghezvisznek, vagy kezével hív a látvány megtekintésére, vagy haragos arckifejezéssel és sötét tekintettel fenyeget, hogy ne menjenek a közelébe, vagy felhívja a figyelmet valamely veszélyre, esetleg csodás dologra, vagy arra hív, hogy sírjunk vagy nevessünk vele együtt." Leon Battista AlBerTi, A festészetről (1436), ford. HajNóczy Gábor, Bp., Balassi, 1997, 121.

${ }^{7}$ A festmény Louvre-ban található változatán az egyik képalak rámutat a sírra, amelyen az „Et in Arcadia ego" felirat található. Vö. Nicolas Poussin, Árkádiai pásztorok, 1638-1640, olaj, vászon, 185 x $121 \mathrm{~cm}$, Párizs, Louvre.
} 
nőalak jelenlétének más oka is van: művészi szempontból a kompozíció harmóniája indokolja. Az alakok gesztusaiból kirajzolódó fél S-vonal által a - cselekményt egyetlen drámai pillanatba sürítő - kép intenzívebb hatást kelt: a nőalak és a néző figyelmét a „karéj” közepén elhelyezkedő Médeiára irányítja.

Poussin rajza esetében egyaránt rendelkezésünkre áll a kép és a szöveg, bár - ahogy már utaltam rá - ez utóbbi nem kritika, hanem képleírás. A Médeia-téma következö, 18. századi feldolgozása azért foglal el sajátos helyet a tanulmányban elemzett képek sorában, mert a néző fantáziájára van bízva, hogy megjelenítse a festményt: a kép ugyanis nem maradt fenn, csupán egy viszonylag kevéssé ismert francia művészetkritikus, La Font de Saint-Yenne kritikája alapján lehet róla elképzelésünk.

\section{A hiányzó festmény: az első francia müvészetkritikus véleménye} Pierre Médeiájáról

A francia művészeti életben a 18. század derekán jelentős változások következnek be. A művészetkritika kialakulásához hozzájáruló tényezők közül elsősorban a Szalonoknak nevezett tárlatokat kell megemlíteni, amelyek a Királyi Festészeti és Szobrászati Akadémia tagjainak kétévente, a Louvre „Négyszögletű Termében” (Salon carré) megrendezett kiállításai után kapták nevüket. ${ }^{8} \mathrm{~A}$ tárlatok részét képezik a XV. Lajos korabeli kultúrpolitika adminisztratív programjának, amely - a rokokó festők népszerü, gáláns tárgyú képeivel szemben - a heroikus témákat helyezi előtérbe. Ezekkel az intézkedésekkel párhuzamosan a század első felében a mükedvelők és irodalmárok köreiben megélénkül a festészet iránti érdeklődés.

A müvészetkritika mint önálló irodalmi műfaj megszületése Étienne La Font de Saint-Yenne 1747-ben megjelent Réflexions sur quelques causes de létat présent de la peinture en France (Elmélkedések a franciaországi festészet jelenlegi állapotának okairól) című írásához füződik. La Font a kiállított képet „nyilvánosságra hozott, kinyomtatott könyvhöz” és „színházban előadott darabhoz” hasonlítja, ezzel magyarázza, hogy „mindenkinek joga van ahhoz, hogy ítélkezzék fölötte”. A festők többsége azonban meglehetősen szkeptikusan viszonyul La Font név nélkül megjelent művéhez. Szokatlannak, sőt felháborítónak tartják, hogy egy „laikus”, egy kívülálló - a kritikus - a kép kidolgozásáról (a rajzról, a színről és a fény-árnyék-hatásokról) véleményt alkosson. La Font legföbb érdeme abban áll, hogy megalkotott egy olyan müfajt, amely az őt követő kritikusok - elsősorban Diderot - munkái nyomán bontakozik majd ki. Ez a müfaj a kortárs műalkotások nyilvános és időszakos kiállításáról szóló, kritikai hangvételü

\footnotetext{
${ }^{8}$ A 18. század első évtizedeiben elhanyagolt tárlatok szokását 1737-től élesztik fel. 1737 és 1748 között évente, 1751 és 1791 között pedig két évenként rendeznek Szalonokat. Lásd Richard WrIGLEY, The Origins of French Art Criticism from the Ancien Régime to the Restoration, Oxford, Clarendon Press, 1993, 42.

${ }^{9}$ Étienne La Font de SAInt-Yenne, Réflexions sur quelques causes de létat présent de la peinture en France $(1747)$ = É. L. F. S-Y., CEuvre critique, éd. Étienne Jollet, Paris, ENSB-A, 2001, 45.
} 
írásokat foglalja magába, és elhatárolódik mind a művészettörténettől, mind a művészéletrajzoktól, mind a festészetelmélettől. A kritikusok általában a festmény témaválasztását, a tematikának megfelelő ábrázolást, valamint a szenvedélyek kifejezését méltatják, a képektől pedig elsősorban azt várják el, hogy az érzelmeikre hassanak.

La Font a festészet legfőbb célját a néző tanításában jelöli meg, és úgy tekint a szenvedélyek kifejezésére leginkább alkalmas - történeti festészetre, mint az erkölcsök iskolájára. Az 1746-os tárlaton kiállított képeket protokolláris sorrendben mutatja be: elsőként az Akadémia igazgatója, Carle Vanloo, majd a többi neves festő történeti képeit tárgyalja, kritikai észrevételeket is beleszőve leírásaiba. ${ }^{10} \mathrm{~A}$ vallásos tárgyú képek után tér rá Jean-Baptiste Marie Pierre mitológiai tárgyú, Médeiát ábrázoló festményére. ${ }^{11}$ Mivel azonban ez a kép eltünt, esetleg valahol lappang (tudomásom szerint nem áll rendelkezésre adat a hollétéről), ezért La Font olvasójára hárul a feladat, hogy a leírás alapján elképzelje ezt a „rettenetes témát” ábrázoló festményt, amely azonnal magára vonta a kiállítás látogatóinak a tekintetét: a kép „témáját a mitológiából meríti, Médeiát ábrázolja, amint tőrével éppen leszúrja egyik gyermekét. A gyermekgyilkosság borzalmát nagyon jól érzékelteti e barbár görög nő arcvonásainak kegyetlensége és a kezében tartott, fia vérétől vöröslő tőr, amellyel már lesújtott". ${ }^{12}$ La Font méltatja a gyilkos szenvedély jól sikerült kifejezését a képen, de a kidolgozást illetően hiányosságokat tesz szóvá. Pierre szemére hányja egyebek között a perspektíva szabályainak semmibe vételét:

De a festő ennél jobban is megszerkeszthette volna képét. A gyermek és a szekér helyzete nem valószerü, és nem is előnyös. A sárkányoknak, amelyeknek e jelenet közben húzniuk kell a szekeret, csak a fejük látszik és meglehetősen fantáziátlanok. Iaszón lángokban álló palotája, amelynek csak egy kis része látható, kétértelműségével disszonáns hatást kelt, és nem igazán illik a képbe. ${ }^{13}$

La Font névtelenül megjelent kritikájában egyértelmüen a befogadó szempontja érvényesül. Meglepőnek tűnhet, hogy visszafogott hangvételü bírálatát a korabeli művészek annyira sértőnek találták, hogy szerzője nyílt levélben volt kénytelen mentegetőzni miatta. Azt bizonygatta, hogy a legcsekélyebb mértékben sem állt szándékában megsérteni a festőket, és pusztán a müvészet jobbítása érdekében kritizálja a képeket, köztük Pierre Médeiáját is. ${ }^{14}$ Bár La Font nem tér ki az ábrázolt pillanat

\footnotetext{
${ }^{10}$ A „történeti kép” gyüjtőfogalom a 17. és 18. században a vallásos, mitológiai és történelmi tárgyú festményeket jelenti. Az Akadémia elméletírói és a kritikusok ezt tartották a legtöbbre a festészeti müfajok közül. ${ }^{11}$ Jean-Baptiste Marie Pierre (1714-1789) vallásos és mitológiai tárgyú festmények mellett - ő festette egyebek között a párizsi Szent Rókus templom (Église Saint Roch) két kupolájának mennyezetképeit könnyedebb hangvételü zsánerképeket is alkotott. 1770-től (Boucher-t követően) a király első festője.

${ }^{12}$ LA FONT, i. m., 63-64.

${ }^{13}$ Uo., 64.

${ }^{14}$ Lásd Étienne La Font de SAINT-Yenne, Lettre de l'auteur des Réflexions sur la peinture et de l'examen des ouvrages exposés au Louvre en $1746=$ Euvre critique, i. m., 96-105.
} 
megválasztására, az őt követő kritikusok általában erre a szempontra helyezik a hangsúlyt, és azt tanácsolják a festőknek, hogy lehetőleg a tragikus esemény tetőpontját megelőző pillanatot ragadják meg, mert ez képes arra, hogy megindítsa a nézőt. Ezen a ponton érdemes felidézni a felvilágosodás kori Franciaországban uralkodó Médeia-felfogást, amelyről a Diderot- és d’Alembert-féle Enciklopédia - Jaucourt lovag által írt - szócikke tanúskodik. A szócikk egyértelmüen pozitív színben tünteti fel a varázslónőt: kizárólag olyan szerzőket idéz, akik erényesnek festették le Médeiát. Jaucourt szerint Euripidés meghamisította a történetet, mert a varázslónőnek csupán az volt a büne, hogy túlságosan szerette Iasónt, és a borzalmas gyermekgyilkosság nem más, mint a végzet hatalmának kifejeződése. ${ }^{15}$

La Font leírása alapján a Pierre által megjelenített pillanat a Médeia-történetnek azt a jelenetét viszi színre, amikor a gyilkos anya sárkányfogatán elrepül. Ugyanezt a mozzanatot ábrázolja Carle Vanloo mintegy tíz évvel később megfestett Médeiája is, ám tőle a Diderot által alaposan megbírált 1759-es képen kívül két további festmény is fennmaradt: egy, a kép témáját feldolgozó későbbi, 1760-as változat, valamint egy 1757 és 1759 között keletkezett előtanulmány.

\section{A színpadi Médeia, három változatban: Diderot Vanloo képéről írt kritikája}

Diderot a Friedrich Melchior Grimm által szerkesztett kéziratos lap, a Correspondance littéraire számára írta több mint húsz éven át - 1759 és 1781 között - a Szalon-kritikáit. Akárcsak La Font és a korabeli kritikusok, ő is azt várja el a képektől, hogy az érzelmeihez szóljanak. Szalonjai azért nem gyakoroltak közvetlen hatást a korabeli francia müvészeti életre, mert - ahogyan a bevezetésben láthattuk - általában nem jutottak el a megbírált művészekhez. Diderot első, 1759-es Szalonjában szerepel Carle Vanloo Médeiájáról írt lesújtó kritikája, amely - a kép keletkezéstörténete ismeretében - a mai olvasó szemében túlságosan szigorúnak tünhet. ${ }^{16}$

Ez a Szalon a későbbiekhez képest feltűnően rövid és kevéssé kidolgozott, a kritikus a tárlaton kiállított 146 kép közül mindössze 45-ről ír. La Font-tól eltérően Diderot nem a müfaji hierarchia szerint mutatja be a képeket, hanem úgy, mint egy sétát a Louvre kiállítótermében: ha valamely festmény nem nyeri el a tetszését, azt épp csak megemlíti és továbbhalad, míg az érdeklődését felkeltő képek előtt hosszasabban

\footnotetext{
${ }^{15}$ Louis de JAUCOURT, Médée = Encyclopédie, ou Dictionnaire raisonné des sciences, des arts et des métiers... (1751-1780), éd. Denis Diderot, Jean le Rond D'Alembert, Stuttgart-Bad Cannstatt, Friedrich Frommann Verlag, 1966-1995, X, 292.

16 Carle Vanloo, Mlle Clairon en Médée (Mlle Clairon mint Médeia), 1759, olaj, vászon, 230 x 328 cm, Postdam, Schloss Sanssouci - Neues Palais. http://utpictura18.univ-montp3.fr/GenerateurNotice.php?n umnotice $=$ A5234\&derniere\&tab=A9545-A4500-A5234 (Letöltés ideje: 2017. június 12.) - Lásd SzABó Zsófia, Színházi portréfestészet a 18. századi Európában, doktori disszertáció, ELTE BTK Müvészettörténet-tudományi Doktori Iskola (témavezető: KeLÉNYI György), Bp., 2014, 92-103.
} 
elidőz. E Szalon alapján nyomon követhető, hogyan alakulnak ki egyfelől Diderot esztétikai gondolatai, másfelől a formálódó műfaj stílusjegyei.

Diderot elégedetlen Vanloo 1759-es Médeiájával, minden szempontból bírálja. A történeti festmény iránt támasztott elvárásokat kéri rajta számon, figyelmen kívül hagyva, hogy a Mlle Clairon mint Médeia nem allegorikus kép - mint amilyen (La Font leírása alapján) Pierre festménye lehetett -, hanem színpadi portré. A festmény a kor egyik leghíresebb tragikáját, Mlle Dumesnil ellenlábasát, Mlle Clairon-t ábrázolja. ${ }^{17}$ Diderot elliptikus mondatokban megfogalmazott kritikája elsősorban a kép föszereplöjére vonatkozik. Teljes terjedelmében idézem a szöveget, amely azt is jól tükrözi, milyenek voltak - vagy lehettek - a festmény nézésének szokásai a 18. században.

Végre megnéztük ezt a Iaszónt és Médeiát ábrázoló híres festményt. ${ }^{18} \mathrm{O}$, barátom, ha láttál még silány fércmüvet! Színházi díszlet, annak minden álságával; elviselhetetlenül tobzódó színekkel; egy lehetetlenül bárgyú tekintetü Iaszónnal. Ez a félnótás hüvelyéből kihúzni készül a kardját, így indul harcba egy varázslónő ellen, aki elérhetetlenül felszáll az égbe, meggyilkolt gyermekeit a lába előtt hagyva. Megadta a módját, meg kell hagyni! Médeiának az ég felé kellene tárnia karjait; fejét hátravetnie; haját összezilálnia; nyitott szájából hosszú jajkiáltásokat hallatnia; üres tekintettel néznie; ehelyett látunk egy apró termetü, merev, töpörödött Médeiát, egy kulissza-Médeiát, akin túl sok a ruha; egyetlen vércsepp sem hull a földre tőre hegyéről vagy csorog le a karján; nyoma sincs zilált kuszaságnak, nyoma sincs rettenetnek. Csak nézzük, elkápráztat minket, de nem rendülünk meg tőle. A nő testével érintkező ruhaanyagoknak páncélos a fénye és csillogása; sárgaréz lemeznek vélnénk. A kép előterében a saját vérével áztatott lépcsőkön gyönyörü gyermek fekszik a hátán, de a legcsekélyebb hatást sem képes kelteni. Ennek a festőnek sem gondolatai, sem érzései nincsenek. A szekér túlságosan súlyos. Ha ez a kép nem festmény, hanem falikárpit volna, a kelmefestő külön díjazásra tarthatna igényt. Jobban szeretem a fürdőző nőket ábrázoló képeit. ${ }^{19}$

Diderot mitológiai témájú narratív képként alkotja újra szavakkal Vanloo színházi portréját. Képzeletbeli kompozíciója a Médeia kardjáról a földre hulló vércsepp által volna képes patetikus hatást kelteni a néző lelkében. ${ }^{20}$ Előtanulmányok tanúskodnak róla, hogy a kép kidolgozása során Vanloo több kompozíciós megoldást is

\footnotetext{
${ }^{17}$ Mlle Clairon (Claire-Josèphe Léris, 1723-1803) a Comédie Française színésznője, korának egyik leghíresebb tragikája, aki minden verssort, szót és intonációt előre megtervezett. Az ő nevéhez füződik a színpadi öltözék leegyszerűsödése és az előadói stílus letisztulása.

${ }^{18}$ Vanloo festménye késéssel érkezett az 1759-es tárlatra: XV. Lajos a nyilvános kiállítás előtt szerette volna látni, és a kép annyira elnyerte tetszését, hogy a saját költségén kereteztette be.

${ }^{19}$ Diderot, Salon de 1759, i. m., 91-92.

${ }^{20}$ Michel DeLon, Violences peintes, Recherches sur Diderot et sur l'Encyclopédie, 1995/18-19, 71-79.
} 
tekintetbe vett. Bár a pau-i Szépművészeti Múzeumban látható, 1757 és 1759 között készült olajtanulmány eltér a Potsdamban kiállított végleges változattól, ezen a korai verzión - amelyen a varázslónő jobbjában fáklyát tart, baljának mutatóujjával pedig a földön fekvő gyermekeire mutat - sem látható a Diderot által olyannyira látni vágyott vércsepp. ${ }^{21} \mathrm{Az}$ illendőség (bienséance) elve ugyanis tiltja, hogy a színpadi portré vért jelenítsen meg: a képnek úgy kell patetikus hatást előidéznie, hogy a látvány ne keltsen rémületet a nézőben.

Vanloo Médeia-ábrázolásait szemlélve a 21. századi néző értetlenkedve tűnődik el azon, hogy valóban olyan „silány fércmü” volna-e ez a kép, mint amilyennek Diderot méltatlankodó szavai alapján gondolhatnánk. Más korabeli kritikusok sokkal kedvezőbb véleménnyel voltak a festményről. Az egyik kritika névtelen szerzője - bár Vanloo alakjait erőtlennek ítéli, tetszetős színkezelését pedig csak a dilettáns müértők szemében találja figyelemreméltónak - összességében elismeri a kép érdemeit. ${ }^{22} \mathrm{Az}$ a kérdés is felmerülhet, hogy ha Diderot müvészet- és drámaelméleti írásaiban általában méltatta a patetikus jelenetek ábrázolását, akkor vajon miért nem értékelte jobban Vanloo képét. Amikor a kritikus mesterkéltnek minősíti a Mlle Clairon mint Médeiát, nem veszi tekintetbe a kép keletkezésének körülményeit: azt a tényt, hogy a festmény megrendelésre készült színpadi portré, pontosabban félúton helyezkedik el a színpadi portré és az allegorikus történeti festmény között.

Korabeli feljegyzések beszámolnak arról, hogy 1757-ben az orosz nagykövet felesége, Galicin hercegnő - Mlle Clairon színpadi játéka iránti elragadtatásának kifejezéseképpen - felajánlotta a színésznőnek, hogy az ő költségén készíttessen magáról képet. ${ }^{23}$ A színésznő kedvelt festöjét, Carle Vanloot kéri fel a feladatra, aki HilaireBernard de Longepierre Médée címü darabjának azt a jelenetét választja megfestésre, amelyben Mlle Clairon a Comédie Française színpadán elsöprő sikert aratott. ${ }^{24}$ Longepierre Médeia-feldolgozása azonban közelebb állt az operához, mint a klaszszikus tragédiához, ez magyarázza Vanloo képének erőteljes díszletszerüségét, valamint a pillanat megválasztását. Diderot megsemmisítő kritikájának az a fő oka, hogy narratív festményre számított, amely úgy visz színre egy adott pillanatot, hogy az azt megelőző és az utána következő mozzanatra is utal. Vanloo alkotásán felfedezhető ugyan cselekmény, de csak utalásszerüen. A festmény menekülést ábrázol, de nem a mitológiai Médeia elmenekülését mutatja be a gyermekgyilkosságot követően,

${ }^{21}$ Carle Vanloo, Mlle Clairon en Médée (Mlle Clairon mint Médeia), 1757-1759, olajvázlat, vászon, 63 x $79 \mathrm{~cm}$, Pau, Musée des Beaux-Arts. http://utpictura18.univ-montp3.fr/GenerateurNotice. php?numnotice=A4521 (Letöltés ideje: 2017. június 12.)

${ }^{22}$ [Név nélküli szerzö], Lettre critique à un ami, sur les ouvrages des Messieurs de l'Académie, exposés au Sallon du Louvre (Egy baráthoz írt kritikus hangú levél, az Akadémia művész urainak a Louvre Szalonjában kiállított alkotásairól), s. l., 1759, 6-7.

${ }^{23}$ Lásd Stéphane Lojkine, L'oeil révolté: Les Salons de Diderot, Paris, Jacqueline Chambon, 2007, 277.

${ }^{24}$ Longepierre 1694-es feldolgozása Euripidés drámája alapján készült, a 18. századi francia színházakban ebben a változatban játszották a darabot. Lásd SzABó, i.m., 96. 
hanem azt a jelenetet örökíti meg, amikor a 18. század legnagyobb francia tragikája, Mlle Clairon diadalmasan elhagyja a színpadot. ${ }^{25}$

Amikor Diderot „színházi díszletnek” nevezi Vanloo képét, egyetlen szót sem ejt arról a tényröl, hogy a jelenet modelljéül voltaképpen Mlle Clairon és partnere, Lekain színpadi játéka szolgált. ${ }^{26} \mathrm{~A}$ díszletszerü hatáshoz a rosszul megválasztott pillanat mellett a festményen tobzódó színkavalkád is hozzájárul, amely kevéssé alkalmas a tragikus szenvedélyek, köztük a rettenet megjelenítésére. A kritikus az 1763-as Szalonban is megvetően nyilatkozik a kép színkezeléséről: Vanloo Gráciái kapcsán ironikusan megismétli, hogy a festő Médeiája a „színezés mesterműve”, nem pedig egy kolorista festő alkotása. ${ }^{27}$ Diderot történeti festményként tekint Vanloo képére, és ebből a szempontból bírálja. Azt szerette volna, ha a festményen - a mesterkéltség és színpadiasság helyett - zürzavart és rettenetet lát: végső soron a szenvedélyek kifejezésének, a patetikus és tragikus dimenziónak a hiányát teszi szóvá. ${ }^{28}$

Az 1759-es képet Vanloo egy évvel később átdolgozta azon kritikák alapján, amelyek eljutottak hozzá (Diderot-é nem tartozott ezek közé), az eredmény a téma öszszefogottabb és kevésbé harsány színekkel megfestett változata lett. ${ }^{29}$ Ezen a kisebb méretü képen Médeia alakja nyúlánkabb, a kompozíció erőteljesebb, a cselekmény pedig drámaibb hatást kelt. ${ }^{30} \mathrm{~A}$ Vanloo által ábrázolt három Médeia-változat közül azonban csak az 1759-esről születtek kritikák, ez volt ugyanis kiállítva a Szalonon. A korabeli kritikusok véleménye közül Diderot-ét emeltük ki, amely az olvasó képzeletében anélkül is élénk hatást kelt, hogy látná a képet, mindenesetre könnyebb elképzelni, mint - La Font leírása alapján - Pierre festményét. Bár az 1759-es Diderot első Szalonja, már itt is megmutatkoznak azok a stílusjegyek, amelyek miatt méltán

\footnotetext{
${ }^{25}$ A korabeli színpadi gyakorlatban az illúziót keltő díszleteket általában egy keretre kifeszített vászonra festették fel, a színészek pedig az allegorikus festményalakok társaságában játszották el szerepüket. A Médeia-darab esetében azonban ennél jóval látványosabb színpadtechnikai megoldáshoz folyamodtak: a varázslónő szekerét gép segítségével emelték a magasba. Az Enciklopédia színházi szerkezeteket (Machines de Théâtre) bemutató metszete a Comédie Française Médeia-jelenetével szemlélteti az emelőszerkezet működését. Lásd LoJKINE, i. m., 285.

${ }^{26}$ A Lekain néven ismertté vált Henri-Louis Cain (1727-1778) a 18. század derekán a legnépszerűbb francia férfiszínész, Longepierre Médeiájában ő játszotta Iasón szerepét.

${ }^{27}$ Diderot, Salon de 1763, i. m., 184.

${ }^{28}$ Lásd Pierre Frantz, De la théorie du théâtre à la peinture: réflexions en marge d’un tableau de Van Loo, Mademoiselle Clairon en Médée = Les Salons de Diderot: Théorie et écriture, éd. Pierre Frantz, Élisabeth LAVEzZI, Paris, PUPS, 2008, 38-39.

${ }^{29}$ Carle Vanloo, Mlle Clairon en Médée (Mlle Clairon mint Médeia), 1760, olaj, vászon, 79 x 59 cm, Postdam, Schloss Sanssouci - Neues Palais. http://utpictura18.univ-montp3.fr/GenerateurNotice. php?numnotice=A4500 (Letöltés ideje: 2017. június 12.) Lásd ehhez: SzABó, i. m., 97.

${ }^{30}$ Több anekdota is fennmaradt azzal kapcsolatban, hogy Vanloo a bírálatok nyomán átdolgozta képeit. Ennek legjellemzőbb példája a Gráciák címü festménye, amelyet 1763-ban a kritikusok elmarasztaltak, Vanloo pedig a Szalon bezárása után megsemmisített. Két év múlva az újabb tárlaton a Gráciák átdolgozott változatát állították ki. (Carle VANLoo, Les Grâces, 1765, Château de Chenonceaux) Diderot kritikája azonban erről a képről sem kedvező, sőt, gyengébbnek ítéli az 1763-as verziónál. Vö. Denis DidERot, Salon de 1765, éd. Else Marie Bukdahl, Annette Lorenceau, Paris, Hermann, 1984, 34.
} 
tekinthető a legnagyobb 18. századi művészetkritikusnak: az erősen szubjektív hangvétel, de mindenekelőtt a „szavakkal való láttatás” képessége. Ezek a sajátosságok jellemzik majd a következő század kritikusait, így Théophile Gautier írásmódját is, azzal a különbséggel, hogy ő általában visszafogottabb hangvételü bírálatokat ír, mint Diderot, és inkább a művek értékeit méltatja, mintsem hibáikat hangsúlyozza.

\section{Delacroix Örjöngő Médeiája és Gautier lelkesült kritikája}

Eugène Delacroix 19. századi irodalmi és művészetkritikai fogadtatásával kapcsolatban elsőként valószínüleg Charles Baudelaire Szalonjai és A fároszok címü költeménye jut az olvasó eszébe. Ez utóbbinak több magyar fordítása is ismeretes, közülük a Faludy György által készített változatban található az alábbi idézet: „Delacroix, nagy vértó, hol démonok tanyáznak, / $\mathrm{S}$ a mély, setét szemekben vak rémület szorong". ${ }^{31}$ Bár a francia eredetiben nem szerepelnek a „mély, setét szemek”, ez a kép - amely a Delacroix által megjelenített világ félelmetes, démoni oldalára helyezi a hangsúlyt kitűnően megidézi a romantikus festő világának, különösen Őrjöngő Médeiájának (Médée furieuse) hangulatát. ${ }^{32}$ Baudelaire, akinek első Szalonja az 1845-ös, nem ír részletesen a festő 1838-as tárlaton bemutatott Médeiájáról, csupán megemlíti 1846os Szalonjában. Megállapítja, hogy ha „gondolatban végigtekintünk festményeinek során" - a felsorolásban a Dante és Vergilius és a Sardanapal mellett a Médeia is szerepel - „[ú]gy érezzük, mintha valami gyásszertartásnak lennénk a résztvevői”, e képeken ugyanis vigasztalanság, szomorúság és csüggedés uralkodik. ${ }^{33}$

A 19. századi francia művészetkritikával foglalkozó szakmunkák általában több figyelmet szentelnek annak a néhány Szalonnak, amelyeket Baudelaire írt, mint Gautier jóval nagyobb számú művészetkritikai írásának. ${ }^{34} \mathrm{E}$ jelenség hátterében valószínűleg az állhat, hogy Baudelaire kritikáját a mai olvasó közelebb érzi magához, és modernebbnek ítéli, mint Gautier eklektikusabb ízlést mutató bírálatait. Baudelaire - aki Gautier-t a mesterének tekintette és A romlás virágait neki ajánlotta - Gautier hatására kezd el művészetkritikával foglalkozni. A két kritikus azonban nem viszonyul teljesen azonos módon Delacroix-hoz: míg Baudelaire feltétel nélkül csodálja a

\footnotetext{
${ }^{31}$ Charles Baudelaire, $A$ fároszok, ford. Faludy György. http://dia.pool.pim.hu/html/muvek/FALUDY/ faludy00675a/faludy00685/faludy00685.html (Letöltés ideje: 2017. június 12.)

32 „Delacroix, lac de sang hanté de mauvais anges, / Ombragé par un bois de sapins toujours vert”. Charles Baudelaire, Les Phares = Ch. B., Les Fleurs du Mal, Paris, Librairie Générale Française, 1964, 24. Vö. SzABó Lőrinc fordításával: „Delacroix, rőt vértó, melyet zöld fenyves árnyal, / kisérteties és gonosz angyal-tanya”. Charles Baudelaire, A fároszok, ford. Szabó Lörinc = Ch. B., A romlás virágai, szerk. Szabó Lörinc, Bp., Révai, 1943, 101.

${ }^{33}$ Charles Baudelaire, Müvészeti kuriózumok, ford. Csorba Géza, szerk. Julien Cain, Bp., Corvina, 1988, 38.

${ }^{34}$ Gautier azon kevés francia kritikus közé tartozik, akik viszonylag hosszú időn keresztül - 1832 és 1872 között - rendszeresen számot adtak a korabeli müvészetről.
} 
festőt, addig Gautier dicsérő szavaiba némi kritikai felhang is vegyül. Ez azért lehet így, mert a 19. századi kritikusok többségéhez hasonlóan az ő ízlését is a neoklasszicista müvészeteszmény határozta meg, és a "barbár zseninek” tartott, nyughatatlan Delacroix kolorista festészete alapvetően idegen volt a természetétől. ${ }^{35}$ Aligha lehet véletlen, hogy a l’art pour l'art-müvészeteszmény jegyében Gautier elméletben a szín ellenében a vonal - és a forma - elsőbbségét hirdeti. A gyakorlatban, kritikusi tevékenysége során a kolorista Delacroix-t a képein átütő erővel megjelenő költői ihletettség miatt mégis sokra tartja. Gautier rendszerint valamely belső dráma kifejeződését látja meg és értékeli a képeken, így Delacroix mitológiai témájú festményein is, ahol nem a történet általános érvényüségén, hanem a személyes tragédián van a hangsúly. Ezt írja az Örjöngö Médeiáról: „ókori téma, modern felfogásban feldolgozva, és inkább az emberi, mint az eszményi oldalán van a hangsúly; ez az ellentét megdöbbentő hatást kelt". ${ }^{36}$ Gautier írásmódjának legszembetűnőbb sajátossága, hogy míg számot ad festményekről, közben - szavakkal - újraalkotja a képet. ${ }^{37}$ Gautier Delacroix Örjöngő Médeiája esetében is ehhez a módszerhez folyamodik, és azt az érzést próbálja meg az olvasónak átadni, amelyet benne váltott ki a kép. A továbbiakban Delacroix képét Gautier művészetkritikájának fényében mutatom be.

A Delacroix vázlatfüzetében található tanulmányrajzok alapján az Örjöngő Médeia keletkezését viszonylag hosszú felkészülési időszak előzi meg. A festő 1836-ban kezd el a képen dolgozni, amelyet az 1838-as Szalonon állított ki. ${ }^{38}$ Gautier kritikája ebből az alkalomból született: a kritikus méltatja a festményt, amelynek szerzője bátran szakít az akadémiai hagyományokkal. Az 1855-ös párizsi világkiállításon a festő újra bemutatta a képet, amelyet 1862-ben két kisebb formátumú, megrendelésre készült másolat követett. A kép a történet utolsó epizódját ábrázolja, azt a pillanatot, amikor a drámai feszültség a tetőpontjára hág, s Médeia - Iasón árulását megbosszulva - arra készül, hogy megölje két közös gyermeküket. A nőalak szoborszerü jellege nagymértékben hozzájárul ahhoz, hogy a néző statikusnak érzékeli a képet. Gautier így írja le a festmény hátterében látható, kietlen tájat:

\footnotetext{
${ }^{35}$ Gautier személyes ízlése nem mindig esett egybe azzal, mint amit hivatalos művészetkritikusi státusza megkövetelt tőle. Mủvészetkritikájának újraértékelésével kapcsolatban lásd Wolfgang Drost, Pour une réévaluation de la critique d'art de Gautier, Cahiers de l'Association internationale des études françaises, 2003/55, 401-421.

${ }^{36}$ Gautier, Exposition du Louvre, i. m., 34.

${ }^{37}$ Delacroix 1855-ben azért bírálja Gautier-t Naplójában, mert a költő úgy írja le a képeket, hogy maga is képet alkot, ám ez a festö szerint nem valódi kritika. Idézi Drost, i. m., 402.

${ }^{38}$ Eugène Delacroix, Médée furieuse (Őrjöngő Médeia), 1838, olaj, vászon, 260 x 165 cm, Lille, Palais des Beaux-Arts. http://www.pba-lille.fr/Collections/Chefs-d-OEuvre/Peintures-XVI-sup-e-sup-XXI-sup-esup-siecles/Medee (Letöltés ideje: 2017. június 12.) - 1999-ben a lille-i Szépművészeti Múzeum Delacroix Örjöngő Médeiájával kapcsolatos kiállítást szervezett. Az 1838-as, Lille-ben őrzött verzió és az 1862-ben készült két másolat mellett (az egyik a Louvre-ban, a másik magángyüjteményben található) létezett egy, ezektől különböző 1859-es, berlini változat is (amely eltünt vagy lappang). A kiállítás a kép három fennmaradt változatát és ezekhez kapcsolódóan több vázlatot, rajzot és előkészítő festményt mutatott be.
} 


\begin{abstract}
[...] hatalmas kősziklák meredeznek az ég felé, az előtérben pedig hosszúra nőtt, tűhegyes levelü, tüskés szárú, vad és mérgező növények kúsznak-vonaglanak a földön fenyegető tüskéikkel skorpiók vagy siklók módjára; a feldúlt Médeia, kezében tőrrel, zilált öltözékben mintha szét akarná feszíteni a kép keretét; két csodaszép gyermek csimpaszkodik a karjába. ${ }^{39}$
\end{abstract}

Médeia hajában királyi ékszert visel, s ökölbe szorított kezében tartja tőrét, amely azonnal magára vonzza a néző tekintetét. Ez a mozdulat tökéletesen megfelelne Diderot drámai feszültségről alkotott elvének. Üldözői elől Médeia egy barlangba menekült, ahová csupán egy keskeny, háromszög alakú résen át szűrődik be a fény. Médeia erre a fénycsíkra szegezi tekintetét, míg gyermekei kétségbeesetten próbálnak menekülni anyjuk gyilkos szorításából: „a szegény kis áldozatok pufók, bársonyos arcán szétáradó ártatlan pirosság és őrjöngő anyjuk zöldes, bünös, sápadt arcszíne között feszülő ellentét maga a megtestesült poézis". ${ }^{40}$ Mindkét gyermek görcsösen vonaglik, a szőke sír, könnycsepp gördül le az arcán, a barna félig elrejtőzik, szemében félelem és rettenet tükröződik. Vércseppet azonban itt sem látunk, hiszen a tragédiát közvetlenül megelőző pillanatot viszi színre a kép.

Gautier az erős fény-árnyék kontraszt kapcsán megjegyzi, hogy Médeia feje olyan „dühös és gonosz, mint a vipera feje; az arcát kettészelő nagy árnyék, amelyet általában kifogásoltak, szerintünk fokozza a tragikus hatást". ${ }^{41}$ Delacroix ragyogó színkezelése erősen megosztotta a korabeli kritikusokat, akik gyakran disszonánsnak érzékelték a festő képeit. Alkotásainak kétségkívül legszembeötlőbb vonása, hogy kolorista festő művei. Gautier is hangsúlyozza, hogy Delacroix nagyszerű színkezelésével ér el életteli hatást:

Rubens és Jordaens, az emberi test ábrázolásának fejedelmei sem tudnák ezt jobban megfesteni; a karok mintha mozognának és vissza akarnák tartani a gyermekeket, noha végső soron csak két gyermek látható a képen, akik az élet, az egészség és a színkezelés csodái: Delacroix úr gyakran festett ilyen jól, de jobban soha. ${ }^{42}$

Akárcsak a festmény, Gautier kritikája is elsősorban a néző érzelmeihez szól. Az Őrjöngő Médeia ízig-vérig romantikus kép, amely sajátos befogadói magatartást követel meg. Baudelaire így fogalmazza meg ennek a látás- és befogadásmódnak a lényegét: „A romantika nem a tárgyválasztásban vagy a korhüségben, hanem az érzésmódban rejlik." ${ }^{43}$ Ez a megfogalmazás a festészetre vonatkoztatva egyfelől a müvész

\footnotetext{
${ }^{39}$ Gautier, Exposition du Louvre, i. m., 34.

${ }^{40}$ Uo., 34-35.

${ }^{41}$ Uo., 35.

${ }^{42}$ Uo.

${ }^{43}$ Baudelaire, Müvészeti kuriózumok, i. m., 24.
} 
érzésmódjára utal, másfelől a nézőben is ennek megfelelő érzésmódot alakít ki. Hasonló gondolatot fogalmaz meg Naplójában Delacroix, amikor a festészetet és a költészetet összehasonlítva azt vallja, hogy „az író szinte mindent kimond, hogy megértsék. A festészetben egyfajta titokzatos híd jön létre a képalakok és a néző lelke között". ${ }^{44}$

\section{Összegzés}

Tanulmányomban négy - a Médeia-témát feldolgozó, az uralkodó korstílusok szempontjából reprezentatív - 18-19. századi francia kép és a róluk írt kritikák alapján azt a folyamatot próbáltam meg bemutatni, hogy a különböző képi ábrázolások a történet mely aspektusára helyeznek hangsúlyt és Médeia jellemének milyen vonását emelik ki. Poussin rajzával és Pierre - fellelhetetlen vagy megsemmisült - képével ellentétben Vanloo és Delacroix festménye nem ábrázolja magát a gyermekgyilkosságot, csupán utal rá. Ennek hátterében az áll, amit a legutóbb idézett Delacroix-naplórészlet a „titokzatos híd" metaforájával fejezett ki, s ami az ut pictura poesis-gondolat jegyében évszázadokon át meghatározta a müvészetről való gondolkodást: a festészet és az irodalom lehetőségeit és kifejezőeszközeit tekintve alapvetően különbözik egymástól.

Megfigyelhettük, hogy a színház és a festészet szoros összefonódása miatt különösen a 18. századi francia Médeia-ábrázolások erősen dramatizált képek, ami arra vezethető vissza, hogy a 17. században kialakuló francia festészetelmélet (és a következő században megszülető művészetkritika) a retorika mellett a drámaelmélet alapján alakította ki fogalmi apparátusát és szempontrendszerét. Az elemzett Médeia-ábrázolások kritikai fogadtatásai közül Diderot szempontjai voltak a legkevésbé összhangban a bemutatott képpel, $s$ inkább a kritikus saját, művészetről vallott elgondolását tükrözték. A vizsgált képeken Médeia hol varázslónőként, hol szenvedélyes, tragikus nőalakként jelenik meg: ez utóbbi felfogásnak leginkább Delacroix festménye - és Gautier-nak a képet szavakkal újraalkotó kritikája - felel meg. A romantikus művész képén Médeia a szörnyűséges tetthez, a kettős gyermekgyilkossághoz vezető pusztító szenvedély megtestesítője.

Befejezésképpen érdemes volna eljátszani azzal a gondolattal, amelyre a tanulmány elején is utaltam, hogy vajon a különböző korokban élt kritikusok milyen véleménnyel lettek volna a többi említett képről. Ez a gondolatjáték kétségkívül meglepő eredményekhez vezetne. Poussin rajzát és Pierre festményét Diderot minden bizonnyal értékelné a kicsorduló vércsepp látványa miatt (még akkor is, ha ez utóbbi festészetét nem különösebben kedvelte). Ennél még valószínűbb, hogy mindkét 18. századi kritikus - La Font de Saint-Yenne és Diderot is - nagyra tartaná Delacroix Őrjöngő Médeiáját, amely a néző érzelmeire hat. Gautier pedig La Font-nál és

${ }^{44}$ Eugène Delacroix, Journal: 1822-1863, Genève, La Palatine, 1946 (rövidített kiadás), 12. 
különösen Diderot-nál elnézőbben írna Pierre és Vanloo festményéről, bár e képek bizonyára nem jelentenének számára ihletforrást. A legvalószínübbnek mégis az tünik, hogy a Delacroix-féle változat - mégha nincs is rajta vércsepp - mindegyikük tetszését elnyerné. Aligha lehet véletlen, hogy a romantikus művész Médeiája a téma legismertebb, emblematikussá vált ábrázolása a francia festészetben, amelyet a 19. század második felében, Delacroix műve nyomán Paul Cézanne is megfestett. ${ }^{45}$

\section{KaTALIN BARTHA-Kovács}

Representations of Medea in 17th-and 18th-century French painting and art criticism

The article's aim is to analyse three paintings (those of Pierre, de Vanloo and Delacroix) and a drawing attributed to Poussin, all of which have Medea as their subject. Critiques (written by La Font de Saint-Yenne, Diderot and Gautier) and Bellori's description of these pictures are also examined. By the analysis, the article's goal is to shed light on the shifts in the pictorial conception of Medea as a subject, as well as to reveal them in their literary reception in the $17^{\text {th }}$ and $18^{\text {th }}$ centuries. The article seeks to answer - among others - the following questions: what are the criteria that the critics of the Salons insist on? To what extent do they relate to the exhibited image? Or do they rather serve as illustrations for the artistic principles valued by the critics?

${ }^{45}$ Paul Cézanne, Médée, d’après Delacroix (Médeia, Delacroix után), 1880-1885, Zürich, Kunsthaus Zürich. 